\section{Screening Pyrus Germplasm for in Vitro Rooting Response}

\author{
Barbara M. Reed ${ }^{1}$ \\ U.S. Department of Agriculture, Agricultural Research Service, National Clonal \\ Germplasm Repository, 33447 Peoria Road, Corvallis, OR 97333-2521
}

Additional index words. pear, rhizogenesis, Pyronia, micropropagation, tissue culture

\begin{abstract}
Micropropagated shoots of 49 Pyrus species and cultivars and one selection of Pyronia veitchii (Trabut) Guillaumin were evaluated to test their responses to several in vitro rooting techniques. Auxin treatment was required for rooting in most cases. Eighteen of 50 accessions rooted $\geq 50 \%$ with a 15 -second, 10-mM IBA dip followed by growth on medium with no growth regulators (NGR). Twelve accessions rooted on a medium with 10 $\mu_{\mathrm{M}}$ IBA applied for 1 week followed by NGR medium for 3 weeks; NGR medium alone was effective for only two accessions. Twenty-eight accessions rooted poorly with IBA treatments; an additional treatment of a 15-second dip in $10 \mathrm{~mm}$ NAA followed by NGR medium produced $\geq \mathbf{5 0 \%}$ rooting for eight genotypes. Root production increased for 10 of 19 especially recalcitrant genotypes by $10 \mu_{\mathrm{M}} \mathrm{IAA}$ treatments in darkness or at 30C and NAA dip treatments. Of rooted shoots, $73 \%$ survived acclimation in the greenhouse. Selections of Pyrus betulifolia Bunge, $P$. calleryana Decne., $P$. hondoensis Kikuchi and Nakai, $P$. koehnei C. Schneider, P. pashia Buch.-Ham. ex D. Don, P. pyrifolia (Burm.f.) Nakai cv. Shinseiki, $P$. regelii Rheder, $P$. ussuriensis Maxim., and the Pyronia veitchii selection failed to root in any of the treatments. Twenty-five of $32 P$. communis $L$. cultivars and three other species rooted on at least one of the treatments. Chemical names used: 1-naphthaleneacetic acid (NAA), $1 H$-indole-3-butyric acid (IBA), $1 H$-indole-3-acetic acid (IAA).
\end{abstract}

Rooting pears (Pyrus spp.) in vitro has proven difficult, and scion cultivars are more difficult than those of rootstocks (Bhojwani et al., 1984). Several methods have been used to induce roots on micropropagated pears. DolcetSanjuan et al. (1990) suggested placing shoots on medium with $10 \mu \mathrm{M}$ IBA for 1 week or dipping them in $10 \mathrm{~mm}$ IBA for $12 \mathrm{sec}$, followed by placement on a hormone-free medium. On $P$. pyrifolia, NAA with $1,3,5$, trihydroxybenzene (phloroglucinol) reduced basal callusing and increased rooting from $30 \%$ to $58 \%$ (Bhojwani et al., 1984). Rooting micropropagated shoots of $P$. calleryana cv. Bradford was unsuccessful with various IBA treatments (Stimart and Harbage, 1989), and P. calleryana cv. Oregon Pear Rootstock (OPR) 157 rooted poorly with IBA or NAA treatments (Yeo and Reed, 1995). Pyrus calleryana cv. OPR 191, however, rooted readily on standard rooting medium (DolcetSanjuan et al., 1990). NAA produced good rooting of 'Seckel' pear with limited callus production on the cutting (Singha, 1980). Pyrus communis cultivars rooted successfully using either NAA or IBA (Rodriguez et al., 1991; Viseur, 1987). Cheng (1979) used IBA at a range of concentrations for successful rooting of various fruit tree rootstocks. Collet (1988)

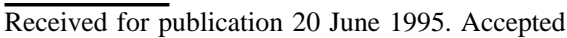
for publication 15 July 1995 . We greatly appreciate the technical assistance of Carolyn Paynter, Lisa Hunt, Traci DeWilde, and Elisa Pandolfi. Use of trade names in this publication does not imply endorsement by the U.S. Dept. of Agriculture. The cost of publishing this paper was defrayed in part by the payment of page charges. Under postal regulations, this paper therefore must be hereby marked advertisement solely to indicate this fact. recommended the brief induction pretreatment of an IBA dip followed by transfer to hormone-free medium to induce the rooting stage for apple (Malus domestica Borkh.) and quince (Cydonia oblonga Mill.) cultivars. Although many approaches have been tried, there is no consensus as to the best method for rooting pear microcuttings, and great genotype differences have been observed. This study was designed to screen a large group of pear genotypes for response to techniques that produced roots on $>50 \%$ of pear shoots in other studies.

\section{Materials and Methods}

In vitro plantlets of 50 accessions (49 Pyrus species and cultivars and one Pyronia veitchii selection), maintained on medium without growth regulators, were removed from cold storage (4C) and multiplied on Cheng's basal medium (Cheng, 1979) with (per liter) $1 \mathrm{mg}$ $\mathrm{N}^{6}$-benzyladenine, $3 \mathrm{~g}$ agar (Bitek; Difco, Detroit, Mich.), and $1.75 \mathrm{~g}$ Gelrite (Schwizerhall, South Plainfield, N.J.) at pH 5.2. Growth regulators were obtained from Sigma Chemical Co., St. Louis. Cultures were grown in Magenta GA7 culture vessels (Magenta Corp., Chicago) at $25 \mathrm{C}$ under a 16 -h photoperiod with $25 \mu \mathrm{M} \cdot \mathrm{m}^{-2} \cdot \mathrm{s}^{-1}$ irradiance provided by coolwhite fluorescent bulbs.

Rooting treatments. Shoots were tested for rooting with the following treatments: 1 ) basal medium with no growth regulators (NGR) (4 weeks), which served as the control; 2) 15-sec dip in $10 \mathrm{~mm}$ IBA dissolved in dimethyl sulfoxide (Sigma) followed by growth on NGR medium (4 weeks); 3) 10- $\mu$ M IBA medium (1 week) followed by NGR medium (3 weeks); 4) 15 -sec dip in $10 \mathrm{~mm}$ NAA dissolved in DMSO followed by NGR medium (4 weeks);
5) treatment 3 in darkness ( 3 weeks) followed by light ( 1 week); 6$)$ treatment 3 at $30 \mathrm{C} \mathrm{(4}$ weeks).

Screening. Initial screening was performed on all 50 accessions to determine the effect of treatments 1, 2, and 3. From each accession, nine shoots (20 to $25 \mathrm{~mm}$ long) were grown in each box with two replications per treatment $(n=18)$. Data were taken on percent rooting at 4 weeks. The number of roots produced, root length, and diameter of callus were determined for each shoot

Twenty-eight accessions also were tested with treatment 4 . Eighteen pears and the Pyronia veitchii accession were tested with treatments 5 and 6. Many of these accessions were chosen for further testing because they did not respond to the other treatments. Data were collected after 4 weeks. All treatments, tested on the groups of 28 (treatment 4) and 19 (treatments 5 and 6) accessions, were performed twice $(\mathrm{n}=18)$. Analysis of variance and means comparison $(P \leq 0.05)$ were performed using MSTAT software (Michigan State Univ., East Lansing).

Acclimatization. Rooted shoots of pear accessions with $\geq 50 \%$ rooting frequency were transferred to the greenhouse for acclimatization and greenhouse culture. Rooted plantlets were washed in tap water to remove culture medium and were planted in perlite in a mist bed for 2 weeks, followed by 2 weeks in the greenhouse. Greenhouse conditions were $\approx 30 \mathrm{C}$ days/20C nights with 16-h days (natural lighting). Percent survival was noted 4 weeks after planting.

\section{Results}

Screen of 50 accessions. The 50 accessions tested showed wide variation in response to the first three rooting treatments (Table 1). Of 50 accessions, $28 \%$ rooted at $\geq 50 \%$ on at least one of the three treatments; $22 \%$ failed to form roots. Twenty-two of the 50 accessions rooted $(\geq 50 \%)$ on one of the IBA treatments, and eight rooted on both. Averaged over all genotypes, growth on NGR produced roots on $<10 \%$ of shoots; three times as many rooted with IBA in the medium (Table 2). The IBA dip treatment was significantly better $(P \leq$ $0.05)$ than the control, but not significantly different from the $10-\mu \mathrm{M}$ IBA treatment, indicating that the amount of IBA present was suitable for root induction in both IBA treatments. There were no significant differences in root length, roots per shoot or callus size between the IBA treatments. Callus formation, roots produced, and percent rooting tended to be positively associated in most of the pear genotypes.

Screen of 28 poor-rooting accessions. A group of 28 accessions, consisting mainly of poorly rooting $(<50 \%)$ cultivars, were tested for rooting response to a 15 -sec, $10-$ mM NAA dip followed by NGR medium (Tables 1 and $3)$. For this group, NAA and IBA dips produced results better than NGR, but the results were not significantly different from each other. The IBA treatments produced similar results, but NAA was significantly better for promot- 
ing rooting than $10 \mu \mathrm{M}$ IBA. Eight of the 28 accessions did not root with any treatment. Root length, roots per plant, and the amount of callus production were influenced by treatment. The best rooting treatments (NAA and IBA dip) generally produced more roots and more callus than less effective treatments.

Screen of 19 accessions with the entire treatment set. For 19 poorly rooting genotypes, the percentages of shoots rooting for the NGR and 10- $\mu \mathrm{M}$ IBA treatments were significantly lower $(P \leq 0.05)$ than for the other treatments (Tables 1 and 4). Rooting on NGR was low $(3.3 \%)$, and $>16 \%$ of shoots rooted with the IBA dip, the NAA dip, the IBA in darkness, and the IBA at 30C. Only $27 \%$ of 19

Table 1. The effect of six rooting treatments on the percentage of shoots rooting in 39 Pyrus genotypes.

\begin{tabular}{|c|c|c|c|c|c|c|}
\hline \multirow[b]{3}{*}{ Accession } & \multicolumn{6}{|c|}{ Shoots rooting $(\%)^{\mathrm{z}}$} \\
\hline & \multicolumn{6}{|c|}{ Treatment $^{y}$} \\
\hline & 1 & 2 & 3 & 4 & 5 & 6 \\
\hline \multicolumn{7}{|l|}{ P. communis cultivars } \\
\hline Admiral Gervais & 0 & 11 & 0 & 33 & 33 & 0 \\
\hline Alliance Franco-Russe & 0 & 22 & 28 & 11 & $--^{x}$ & --- \\
\hline Bartlett - Max Red & 28 & 67 & 39 & --- & --- & --. \\
\hline Bartlett - Striped & 6 & 33 & 39 & --- & --- & --- \\
\hline Belle Julie & 6 & 50 & 17 & --- & --- & -.- \\
\hline Bergamote Tardive de Ganzel & 33 & 28 & 6 & 78 & --- & --- \\
\hline Beurre d'Amanlis Panachee & 6 & 22 & 33 & 78 & --- & --- \\
\hline Beurre Hardy & 6 & 63 & 78 & 89 & --- & --- \\
\hline Butirra Precoce Morettini & 0 & 0 & 44 & --- & --- & --- \\
\hline Cascade & 11 & 89 & 33 & --- & --- & --- \\
\hline Citron d'Ete & 22 & 56 & 22 & --- & --- & --- \\
\hline Clapp Favorite & 0 & 94 & 78 & --- & --- & --- \\
\hline Colonel Wilder & 17 & 67 & 94 & --- & --- & --- \\
\hline Columbia & 15 & 44 & 28 & 39 & 39 & 67 \\
\hline Count A.W. Moltke & 6 & 89 & 50 & --- & --- & --. \\
\hline Douglas & 0 & 33 & 0 & 44 & 11 & 0 \\
\hline Fondante de Charneu & 17 & 61 & 44 & --- & 33 & 100 \\
\hline \multicolumn{7}{|l|}{ Gliva Ukrainskaya/ } \\
\hline Wilenska Plenna & 6 & 28 & 39 & 39 & 56 & 44 \\
\hline Kalle & 22 & 44 & 50 & 89 & 33 & 72 \\
\hline Madame du Ballett & 0 & 0 & 0 & 22 & 56 & 6 \\
\hline Marchland & 17 & 44 & 6 & 56 & --- & --- \\
\hline MM-38 (rootstock) & 0 & 33 & 11 & 22 & --- & --- \\
\hline Monchallard & 6 & 72 & 50 & 33 & --- & --. \\
\hline \multicolumn{7}{|l|}{ Nijisseiki $^{w}$ x } \\
\hline OH (decline susceptible) & 61 & 72 & 89 & --- & --- & --- \\
\hline Notaire Lepin & 0 & 33 & 39 & --- & --- & --- \\
\hline OPR-1 (rootstock) & 22 & 11 & 56 & --- & --- & --- \\
\hline Poirier Fleurissant Tard & 39 & 78 & 39 & --- & --- & --- \\
\hline Rosee de Juillet & 6 & 61 & 22 & --- & --- & --- \\
\hline Vineland 29018 & 0 & 33 & 50 & --- & --- & -.- \\
\hline \multicolumn{7}{|l|}{ P. communis rootstock } \\
\hline$(\mathrm{P}-2366)(\mathrm{F} .12-173)$ & 0 & 61 & 11 & 56 & 0 & 0 \\
\hline \multicolumn{7}{|l|}{ P. communis rootstock } \\
\hline (P-2462)(G.28-119) & 0 & 39 & 61 & 100 & --- & --- \\
\hline$P$. cordata Desv. & 0 & 72 & 6 & --- & --- & --. \\
\hline P. cossonii Rheder & 50 & 72 & 83 & --- & --- & --- \\
\hline \multicolumn{7}{|l|}{ P. dimorphophylla Makino $\mathrm{x}$} \\
\hline$P$. species & 0 & 61 & 11 & 78 & --- & --- \\
\hline P. elaegrifolia Pallas (hybrid) & 6 & 6 & 17 & 22 & 6 & 33 \\
\hline P. koehnei C. Schneider (808) & 0 & 11 & 6 & 0 & 44 & 0 \\
\hline P. koehnei (812) & 0 & 0 & 0 & 0 & 44 & 0 \\
\hline Good Christianv ${ }^{v}$ & 39 & 89 & 72 & --- & --- & --- \\
\hline Mien Suan $\mathrm{Li}^{u}$ & 0 & 11 & 0 & 0 & 11 & 0 \\
\hline
\end{tabular}

${ }^{2}$ Bold type indicates highest rooting percentage.

y 1 = no growth regulator (NGR) medium ( 4 weeks), 2 = 10-mu IBA dip followed by NGR medium ( 4 weeks), $3=10-\mu$ M IBA medium ( 1 week) followed by NGR medium ( 3 weeks), $4=10$-mм NAA dip followed by NGR medium ( 4 weeks), $5=$ treatment 3 in darkness ( 3 weeks) then light ( 1 week), $6=$ treatment 3 at 30C (4 weeks) $(\mathrm{n}=18)$

${ }^{\mathrm{x}}$ Not tested.

${ }^{\text {w }}$ Pyrus pyrifolia.

${ }^{\vee}$ Pyrus pyrifolia (Burm. f.) Nakai x P. communis.

"Pyrus ussuriensis Maxim.

accessions rooted $\geq 50 \%$ with any of the treatments tested, and $22 \%$ did not root at all. Roots were longest with the IBA-dark and IBA-30C treatments, but roots per shoot were most abundant with NAA. The IBA-dark treatment produced significantly more callus than the others, and NGR produced the least. Rooting on $10 \mu \mathrm{M}$ IBA in darkness was the best treatment for 'Admiral Gervais', 'Gliva Ukrainskaya/Wilenska Plenna', 'Madame du Ballett', and two accessions of P. koehnei (Table 1). 'Columbia', 'Fondante de Charneu', 'Kalle', and P. elaegrifolia Pallas rooted well on $10 \mu \mathrm{M}$ IBA at 30C.

Variation by genotype. The 39 Pyrus accessions that rooted were highly variable in survival (100\% for 'Clapp Favorite', 'Colonel Wilder', 'Count A.W. Moltke', 'Fondante de Charneu', 'Bartlett', 'Kalle', 'Rosee de Juillet', 'Citron d'Ete', and 'Poirier Fleurissant Tard'), but a few, such as $P$. cordata Desv. and $P$. ussuriensis, died.

\section{Discussion}

In many genera, rooting of micropropagated shoots can be accomplished by removing cytokinins from the growth medium (Arrillaga et al., 1991; Kerns and Meyer, 1986). In pear and other woody plants, this approach is less successful than auxin treatments (Bhojwani et al., 1984; Dolcet-Sanjuan et al., 1990; Manzanera and Pardos, 1990). Poor rooting on hormone-free medium was confirmed by this screen, with only $9 \%$ of genotypes rooting without auxin treatment. IBA has been a successful rooting treatment for in vitro cultures (Collet, 1988; Corte-Olivares et al., 1990; Dolcet-Sanjuan et al., 1990; Manzanera and Pardos, 1990) and has produced $\geq 50 \%$ rooted shoots in $44 \%$ of the pear genotypes that I tested. The production of roots on shoots treated with IBA was associated with increased callus production. The increased rooting that occurred with increased callus formation must be balanced with a rise in root fragility and increased susceptibility to fungal infection during acclimatization that may cause losses at transplanting (Banno et al., 1989).

Bhojwani et al. (1984) and Dolcet-Sanjuan et al. (1990) found that some genotypes responded better to NAA than to IBA. In this screen, individual genotypes, such as 'Admiral Gervais', 'Bergamote Tardive de Ganzel', 'Beurre d'Amanlis Panachee', and 'Kalle', responded better to NAA, but for others, NAA and IBA led to similar results (Table 1). In this study, following dark treatment, more callus formed at the base of pear shoots; this increase also was noted by Dolcet-Sanjuan et al. (1990).

Due to the variable rooting response in the genus Pyrus, it is difficult to predict which genotypes will root with a particular treatment. In many tree species in the Rosaceae (Nemeth, 1986), rooting has depended on genotype. Mature shoots of other woody species 
are also variable in their response to rooting treatments (Arrillaga et al., 1991). Micro-grafting of shoots onto seedling rootstocks may be the only option available for recalcitrant genotypes (Fridlund, 1989). Survival rates reported for transplanted, in vitro-grown pear shoots vary from $30 \%$ to $90 \%$ for $P$. communis cultivars (Marino, 1988; Rodriguez et al., 1991; Viseur, 1987) and 50\% to $73 \%$ for P. pyrifolia

seedling-derived shoots (Bhojwani et al., 1984). Acclimation was highly successful for most of the pear genotypes screened.

\section{Conclusions}

The results of this screen mainly should serve as guides for more detailed comparisons of particular genotypes and for testing addi-

Table 2. Effect of IBA treatments on mean percentage of shoots rooting, root length, roots per shoot, and callus diameter of 49 Pyrus and one Pyronia veitchii accession.

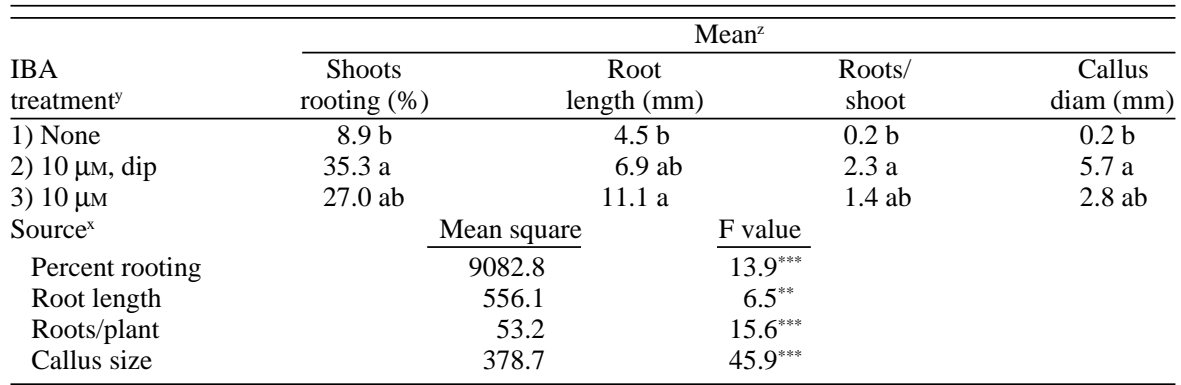

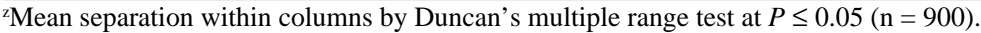

${ }^{y} 1$ = no growth regulator (NGR) medium (4 weeks), 2 = 10-mm IBA dip followed by NGR medium (4 weeks), and $3=10-\mu \mathrm{m}$ IBA medium ( 1 week) followed by NGR medium ( 3 weeks).

${ }^{x}$ Variation between treatments: two degrees of freedom.

${ }^{* *},{ }^{* * *}$ Significant at $P \leq 0.01$ or 0.001 , respectively.

Table 3. Effect of IBA and NAA treatments on mean percentage of shoots rooting, root length, roots per shoot, and callus diameter of 28 difficult-to-root pear accessions.

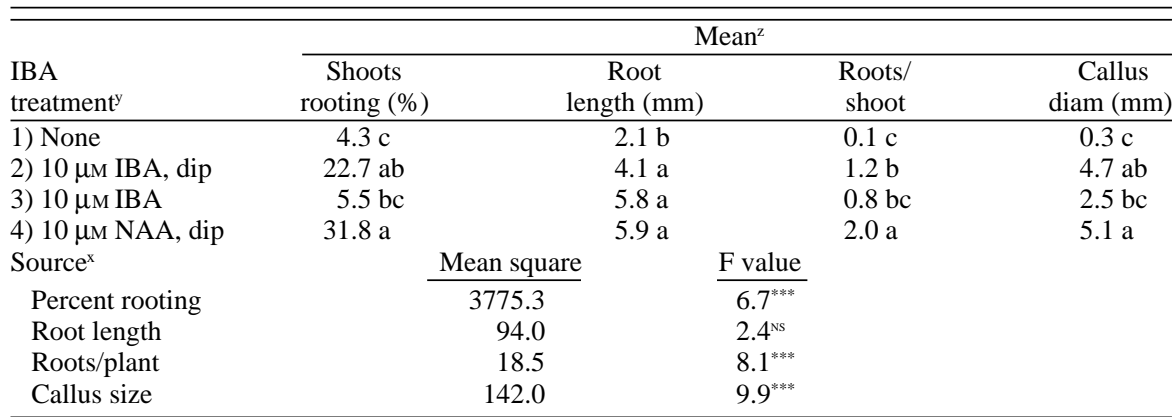

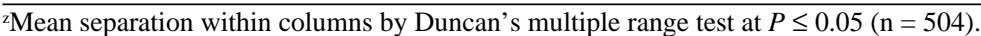

${ }^{\mathrm{y}} 1$ = no growth regulator (NGR) medium (4 weeks), $2=10$-mM IBA dip followed by NGR medium ( 4 weeks),

$3=10-\mu \mathrm{M}$ IBA medium ( 1 week) followed by NGR medium ( 3 weeks), and $4=10$-mM NAA dip followed by NGR medium (4 weeks).

${ }^{x}$ Variation between treatments: three degrees of freedom

Ns, *** Nonsignificant or significant at $P \leq 0.001$, respectively.

Table 4. Effect of six rooting treatments on mean percent rooting, root length, roots per shoot and callus diameter of in vitro cultured shoots of 19 difficult-to-root pear genotypes.

\begin{tabular}{|c|c|c|c|c|}
\hline \multirow[b]{2}{*}{$\begin{array}{l}\text { IBA } \\
\text { treatment }^{y}\end{array}$} & \multicolumn{4}{|c|}{ Mean $^{2}$} \\
\hline & $\begin{array}{c}\text { Shoots } \\
\text { rooting }(\%)\end{array}$ & $\begin{array}{c}\text { Root } \\
\text { length }(\mathrm{mm})\end{array}$ & $\begin{array}{c}\text { Roots/ } \\
\text { shoot }\end{array}$ & $\begin{array}{c}\text { Callus } \\
\operatorname{diam}(\mathrm{mm})\end{array}$ \\
\hline 1) None & $3.3 \mathrm{c}$ & $1.4 \mathrm{c}$ & $0.1 \mathrm{~d}$ & $0.1 \mathrm{~d}$ \\
\hline 2) $10 \mu \mathrm{M}$ IBA, dip & $16.4 \mathrm{a}$ & $3.1 \mathrm{~b}$ & $1.0 \mathrm{~b}$ & $2.8 \mathrm{~b}$ \\
\hline 3) $10 \mu \mathrm{MIBA}$ & $10.3 \mathrm{~b}$ & $3.4 \mathrm{~b}$ & $0.5 \mathrm{c}$ & $1.2 \mathrm{~cd}$ \\
\hline 4) $10 \mu \mathrm{M}$ NAA, dip & $20.3 \mathrm{a}$ & $3.2 \mathrm{~b}$ & $1.4 \mathrm{a}$ & $3.2 \mathrm{~b}$ \\
\hline 5) $10 \mu \mathrm{M}$ IBA, dark & $20.0 \mathrm{a}$ & $5.4 \mathrm{a}$ & $1.0 \mathrm{ab}$ & $4.9 \mathrm{a}$ \\
\hline 6) $10 \mu \mathrm{M} \mathrm{IBA}, 30 \mathrm{C}$ & $17.0 \mathrm{a}$ & $5.7 \mathrm{a}$ & $0.9 \mathrm{bc}$ & $2.3 \mathrm{bc}$ \\
\hline Source $^{\mathrm{x}}$ & \multicolumn{2}{|c|}{ Mean square } & F value & \\
\hline Percent rooting & \multicolumn{2}{|c|}{806.2} & $1.7^{\mathrm{Ns}}$ & \\
\hline Root length & \multicolumn{2}{|c|}{49.0} & $1.2^{\mathrm{Ns}}$ & \\
\hline Roots/plant & \multicolumn{2}{|c|}{4.0} & $2.1^{\mathrm{Ns}}$ & \\
\hline Callus size & \multicolumn{2}{|c|}{52.2} & $7.6^{* * * *}$ & \\
\hline
\end{tabular}

${ }^{2}$ Mean separation within columns by Duncan's multiple range test at $P \leq 0.05(\mathrm{n}=342)$

y 1 = no growth regulator (NGR) medium (4 weeks), $2=10$-mm IBA dip followed by NGR medium (4 weeks), $3=10-\mu$ IBA medium (1 week) followed by NGR medium ( 3 weeks), $4=10$-mm NAA dip followed by NGR medium ( 4 weeks), $5=$ treatment 3 in darkness $(3$ weeks) then light $(1$ week), and $6=$ treatment 3 at 30C (4 weeks).

${ }^{x}$ Variation between treatments: five degrees of freedom.

Ns, *** Nonsignificant or significant at $P \leq 0.001$, respectively. tional auxin concentration-duration combinations. Accordingly, I recommend that an IBA or NAA dip treatment be used for rooting pear genotypes of unknown rooting potential. The $10-\mu \mathrm{m}$ IBA (treatment 3) and 10-mm IBA dip (treatment 2) procedures were especially suitable for $P$. communis cultivars, with $10 \mathrm{~mm}$ NAA as an alternative for those that did not respond to IBA. For especially recalcitrant genotypes, treatment with $10 \mu \mathrm{M}$ IBA during 3 weeks in darkness or 4 weeks at $30 \mathrm{C}$ in the light are suggested.

\section{Literature Cited}

Arrillaga, I., T. Marzo, and J. Segura. 1991. Micropropagation of juvenile and adult Sorbus domestica L. Plant Cell Tissue Organ Cult. 27:341-348.

Banno, K., K. Yoshida, S. Hayashi, and K. Tanabe. 1989. In vitro propagation of Japanese pear cultivars. J. Jpn. Soc. Hort. Sci. 58:37-42.

Bhojwani S.S., K. Mullins, and D. Cohen. 1984. In vitro propagation of Pyrus pyrifolia. Scientia Hort. 23:247-254.

Cheng, T.Y. 1979. Micropropagation of clonal fruit tree rootstocks. Compact Fruit Tree 12:127-137.

Collet, G.F. 1988. Improvement to induce rooting of fruit trees in vitro. Acta Hort. 227:319-323.

Corte-Olivares, J., G.C. Phillips, and S.A. ButlerNance. 1990. Micropropagation of pecan. HortScience 25:1308.

Dolcet-Sanjuan, R., D. Mok, and M. Mok. 1990. Micropropagation of Pyrus and Cydonia and their responses to Fe-limiting conditions. Plant Cell Tissue Organ Cult. 21:191-199.

Fridlund, P.R. 1989. Thermotherapy, p. 284-295. In: P.R. Fridlund (ed.). Virus and viruslike diseases of pome fruits and simulating noninfectious disorders. Publ. SP0003. Washington State Coop. Ext., Washington State Univ., Pullman.

Kerns, H.R. and M.M. Meyer. 1986. Tissue culture propagation of Acer $\times$ freemanii using thidiazuron to stimulate shoot tip proliferation. HortScience 21:1209-1210.

Manzanera, J.A. and J.A. Pardos. 1990. Micropropagation of juvenile and adult Quercus suber L. Plant Cell Tissue Organ Cult. 21:1-8.

Marino, G. 1988. The effect of paclobutrazol on in vitro rooting, transplant establishment and growth of fruit plants. Plant Growth Regulat. 7:237-247.

Nemeth, G. 1986. Induction of rooting, p. 49-64. In: Y.P.S. Bajaj (ed.). Biotechnology in agriculture and forestry. vol. 1. Springer-Verlag, Berlin.

Rodriguez, R., C. Diaz-Sala, L. Cuozzo, and G. Ancora. 1991. Pear in vitro propagation using a double-phase culture system. HortScience 26:62-64.

Singha, S. 1980. In vitro propagation of 'Seckel' pear, p. 59-63. In: R.H. Zimmerman (ed.). Proc. Conf. Nursery Production Fruit Plants through Tissue Cult.-Applications and feasibility. U.S. Dept. Agr. Sci. and Educ. Administration, ARR-NE-11.

Stimart, D.P. and J.F. Harbage. 1989. In vitro shoot proliferation of Pyrus calleryana from vegetative buds. HortScience 24:298-299.

Viseur, J. 1987. Micropropagation of pear, Pyrus communis L., in a double-phase culture medium. Acta Hort. 212:117-124.

Yeo, D.Y. and B.M. Reed. 1995. Micropropagation of three Pyrus rootstocks. HortScience 30:620-623. 